Atmos. Chem. Phys., 13, 7783-7793, 2013

www.atmos-chem-phys.net/13/7783/2013/

doi:10.5194/acp-13-7783-2013

(c) Author(s) 2013. CC Attribution 3.0 License.

\title{
Modeling upper tropospheric and lower stratospheric water vapor anomalies
}

\author{
M. R. Schoeberl ${ }^{1}$, A. E. Dessler ${ }^{2}$, and T. Wang ${ }^{2}$ \\ ${ }^{1}$ Science and Technology Corporation Lanham, Columbia, MD, USA \\ ${ }^{2}$ Texas A\&M University, College Station, TX, USA
}

Correspondence to: M. R. Schoeberl (mark.schoeberl@mac.com)

Received: 7 March 2013 - Published in Atmos. Chem. Phys. Discuss.: 11 April 2013

Revised: 24 June 2013 - Accepted: 29 June 2013 - Published: 13 August 2013

\begin{abstract}
The domain-filling, forward trajectory calculation model developed by Schoeberl and Dessler (2011) is used to further investigate processes that produce upper tropospheric and lower stratospheric water vapor anomalies. We examine the pathways parcels take from the base of the tropical tropopause layer (TTL) to the lower stratosphere. Most parcels found in the lower stratosphere arise from East Asia, the Tropical West Pacific (TWP) and Central/South America. The belt of TTL parcel origins is very wide compared to the final dehydration zones near the top of the TTL. This is due to the convergence of rising air due to the stronger diabatic heating near the tropopause relative to levels above and below. The observed water vapor anomalies - both wet and dry correspond to regions where parcels have minimal displacement from their initialization. These minimum displacement regions include the winter TWP and the Asian and American monsoons. To better understand the stratospheric water vapor concentration we introduce the water vapor spectrum and investigate the source of the wettest and driest components of the spectrum. We find that the driest air parcels originate below the TWP, moving upward to dehydrate in the TWP cold upper troposphere. The wettest air parcels originate at the edges of the TWP as well as in the summer American and Asian monsoons. The wet air parcels are important since they skew the mean stratospheric water vapor distribution toward higher values. Both TWP cold temperatures that produce dry parcels as well as extra-TWP processes that control the wet parcels determine stratospheric water vapor.
\end{abstract}

\section{Introduction}

A broad understanding of the stratospheric circulation began over 60 years ago with the publication of Brewer's seminal paper (Brewer, 1949). In order to account for the dryness of the stratosphere, Brewer noted that air must have entered the stratosphere through the extremely cold tropical tropopause. Mass conservation requires that this tropical upward circulation have descending branches in the extra-tropics. Newell and Gould-Stewart (1981), again using stratospheric water vapor observations and tropopause temperature measurements, refined this idea by suggesting that most of the air reaching the stratosphere was moving upward through the very coldest part of the tropical tropopause, the winter Tropical West Pacific (TWP), a region they termed the "stratospheric fountain". Subsequent measurements of tropospheric trace gases suggest that the winter tropical west Pacific is the primary locus of air entering the stratosphere during Boreal winter. On the other hand satellite observations during boreal summer have identified the summer Asian monsoon as another possible region for tropospheric air to enter the stratosphere (Randel, 2010; Bergman et al., 2013). Sherwood and Dessler (2000) defined the Tropical Tropopause Layer (TTL), a transition layer between the troposphere and stratosphere extending from the level of zero net-radiative heating ( $\sim 13-14 \mathrm{~km}, 355-360 \mathrm{~K}$ potential temperature) to the highest level that convection reaches $(\sim 18-19 \mathrm{~km}, 380-400 \mathrm{~K})$. The TTL is sometimes referred to as the "tape-head for the water vapor tape recorder" because tape recorder signals gets stronger with altitude through the TTL (Gettelman et al., 2010). 

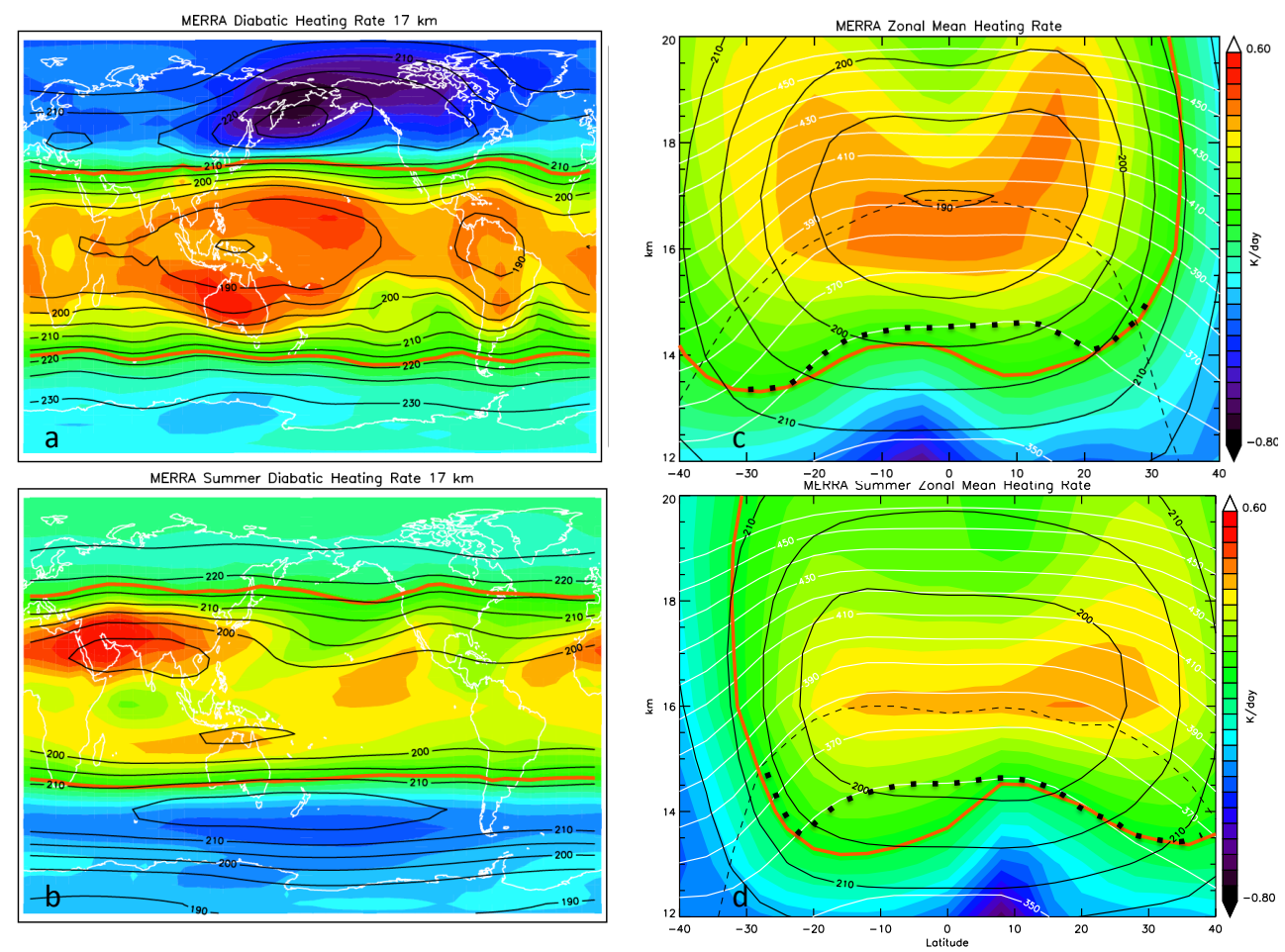

Fig. 1. Heating rates and temperatures from MERRA averaged from 1979-2010. (a), $17 \mathrm{~km}$ map of heating rates for Boreal winter (DJF) with temperatures (black contours). Thin orange line is the zero heating contour. (b), summer (JJA). (c) the zonal mean heating rate and temperatures (black contours) and potential temperatures (white). Dashed line shows the zonal mean tropopause. Black dots illustrate the parcel forcing position used in the model. (d), summer. The color bar next to the right hand figures indicates the heating rate range in $\mathrm{K}$ day ${ }^{-1}$ from -0.8 to $0.6 \mathrm{~K} \mathrm{day}^{-1}$.

Convective detrainment is the primary mechanism by which pollutants from the lower troposphere are deposited into the TTL (Fueglistaler et al., 2009). The TTL base is the primary zone of convective detrainment, although convective detrainment continues above the base of the TTL with decreasing frequency (Dessler, 2002; Zipser, 2006). From a Lagrangian perspective, once air parcels reach the TTL, they move upward due to positive net radiative heating rates. As these parcels ascend towards the tropopause, they encounter colder temperatures. When the parcel's relative humidity exceeds some threshold value, ice forms (Jensen et al., 1996) and is gravitationally removed dehydrating the air parcels. Above the tropopause, temperatures increase and no further dehydration occurs.

Thus, parcel water vapor concentration is primarily determined by the minimum parcel path temperature (e.g. Mote et al., 1996; Holton and Gettelman, 2001; Gettelman et al., 2002; Fueglistaler et al., 2005, 2009; Liu et al., 2010). We refer to the point on the parcel path that fixes the water vapor concentration as the final dehydration point (FDP), which is sometimes called the Lagrangian dry point (Liu et al., 2010) and it is closely related to the Lagrangian cold point (Fueglistaler et al., 2005). As found by Schoeberl and Dessler (2011, hereafter SD2011), maps of the FDP distri- bution show that most parcels complete the dehydration process in the Tropical West Pacific (TWP), as originally theorized by Newell and Gould-Stewart (1981). This does not mean the parcels are entering stratosphere in the same region. In fact, parcel dehydration and the process of entering the stratosphere are different processes that occur on different timescales and in different locations, as we show below.

Below (Sect. 2) we first describe the model set up and the observations that motivate this analysis. Section 3 shows the results of our simulations, our estimates of parcel displacement from initial forcing regions, sources of wet and dry air, and we introduce the water vapor spectrum. Section 4 summarizes our research and ends with conclusions.

\section{Model and observations}

\subsection{Reanalysis datasets and model set up}

The results shown in this paper are from the forward domain filling diabatic trajectory model described in SD2011 and in Schoeberl et al. (2012) (S2012). In this study, we use 6-h wind, temperature and heating rate analyses from NASA's Modern-Era Retrospective Analysis for Research and Application (MERRA, Rienecker et al., 2011), NOAA's Climate 
Forecast System Reanalysis (CFSR, Saha et al., 2010) and ECMWF's ERA Interim reanalysis (ERAi, Dee et al., 2011) to drive the model. These three reanalyses are described and compared in more detail at http://reanalyses.org/atmosphere/ comparison-table. The net diabatic heating rates include all physical processes in the model, such as the radiative effects of gases and clouds, latent heating, and turbulent heating. Forward domain-filling for this study works as follows: Every six hours, corresponding to an analysis time, we use a random number generator to initialize 550 parcels randomly distributed from $0-360^{\circ}$ longitude and $\pm 60^{\circ}$ latitude. For each parcel, the initialization level is chosen to be above the local zero diabatic heating level, but not lower than $360 \mathrm{~K}$ potential temperature or above the tropopause. Our tropopause is determined from the analyses to be the lowest of the following in an atmospheric profile: the cold point, the $2 \mathrm{~K} \mathrm{~km}^{-1}$ lapse rate (the WMO definition), or the $380 \mathrm{~K}$ surface. This means that in the Asian monsoon region, parcels would be initiated at about $370 \mathrm{~K}$ since the level of zero net heating is higher there.

After initialization, the parcels move upward into the stratosphere, filling the stratospheric domain. Generally, parcels move downward at extra tropical latitudes and those moving below $250 \mathrm{hPa}$ are removed - we assume they have re-entered the troposphere. Parcels are initiated with $50 \mathrm{ppmv}$ (parts per million by volume) of water vapor, and we dehydrate parcels to saturation when the relative humidity exceeds a predetermined threshold - in this paper, $100 \%$. We use the saturation over ice temperature - water vapor relationship described in Murphy and Koop (2005). As with most trajectory models of this type we assume that when saturation is reached the excess water vapor is instantly removed to limit relative humidity to $100 \%$. In addition to water vapor, we carry the methane $\left(\mathrm{CH}_{4}\right)$ concentration for each parcel. Methane is oxidized in the stratosphere and the resulting water is added to the parcel, as described in SD2011. Tropospheric methane initial values are increased linearly from $1.54 \mathrm{ppmv}$ in 1979 to $1.8 \mathrm{ppmv}$ in 2010. The oxidation rate of methane is interpolated from a two-dimensional stratospheric chemistry model (Fleming et al., 2007) onto parcel locations.

While the model can include simple parameterization for the effects of gravity waves and convection, as well as allowing for super-saturation (see SD2011), for these experiments we turn off all the parameterizations. Including these additional processes does not affect our results.

In a diabatic trajectory model, the net diabatic heating rate controls vertical transport. Figure 1 shows the time mean Boreal winter (DJF - December, January, February) and summer (JJA - June, July, August) upper tropical troposphere temperatures and heating rate fields at a log-pressure height of $17 \mathrm{~km}(\sim 90 \mathrm{hPa})$. In DJF (Fig. 1a), the strongest heating occurs in the west Pacific region, split across the equator with one zone east of the Philippines and second spread over northern Australia. Secondary heating zones occur over Central and western South America. The strongest cooling zone is co-located with the Aleutian anticyclone (Boville, 1960). All three analyses show that the coldest upper tropospheric tropical temperatures are roughly co-located with the peaks in heating.

In contrast to DJF, JJA (Fig. 1b) shows the strongest heating over the Asian monsoon region extending to the Near East through the Mediterranean, but overall less heating than in DJF. Smaller heating regions are present east of Central America and northern Australia. The coldest time mean summer TTL temperatures are over the Asian monsoon at about $\sim 193 \mathrm{~K}$, but in winter the coldest time-mean TWP temperature is $\sim 188 \mathrm{~K}$. The ice saturation mixing ratio difference for these two temperatures is almost $2.5 \mathrm{ppmv}$ given the same pressure level. The zonal mean heating rate for summer and winter (Fig. 1c and d, respectively) shows that the heating rate is stronger in winter over a broader latitudinal extent than in summer. The black dots in Fig. 1c and d show the parcels' initialization level.

\subsection{Observations}

Most of our comparisons will be with Aura Microwave Limb Sounder (MLS) measurements (Read et al., 2007) made between 2005 and 2010. In S2012 we showed that MERRA and CFSR are in good agreement with Singapore sondes, while ERAi is cold biased. Even a small bias in reanalysis temperatures can produce a significant shift in water vapor concentration (e.g. Randel et al., 2004, S2012) and we see this in our model simulations - ERAi's stratosphere is relatively dry compared to observations and the other models.

\subsection{Water vapor simulations}

Before we explore the various parcel pathways, it is useful to verify the quality of the simulations as compared to MLS observations. Figure 2 shows the water vapor patterns at 100 and $83 \mathrm{hPa}(\sim 16$ and $\sim 17.5 \mathrm{~km})$ from the five-year winter (DJF) and summer (JJA) averages for the MLS and the three reanalyses discussed in SD2012 and above. The model fields are adjusted so that the model zonal mean is the same as the MLS zonal mean. First, we note that the three summer and winter reanalyses water vapor distributions are consistent with MLS and with each other. During DJF, the lowest mixing ratios occur over the TWP with dry features over Africa and Central/South America at $100 \mathrm{hPa}$. Higher up, the TWP low water vapor feature has spread across the tropics to the Indian Ocean and Africa. The bands of high water vapor at higher latitudes are due to methane-enhanced water vapor descending from the mid-stratosphere.

The summer (JJA) $100 \mathrm{hPa}$ model fields show water vapor enhancements over the Asian monsoon and Central/ South America associated with monsoonal circulations. The models also show a dry feature over the Indian Ocean that extends into the West Pacific. This dry feature is not as evident in MLS data; MLS observes the feature further east. At $83 \mathrm{hPa}$ 

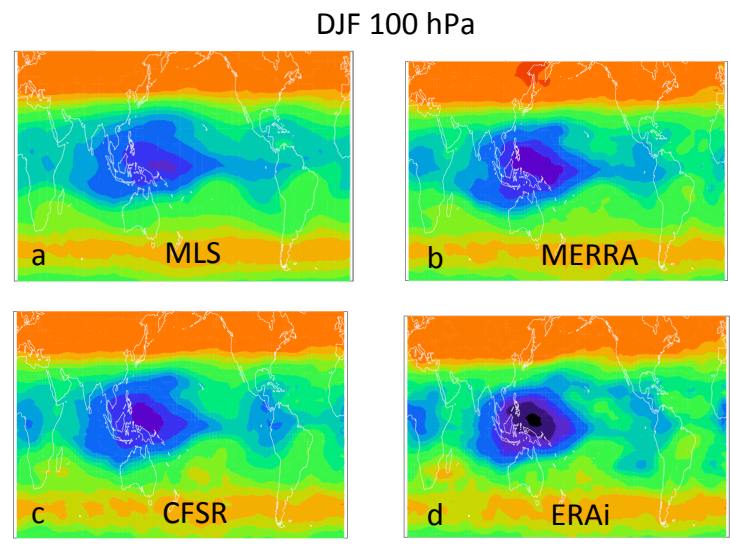

DJF $83 \mathrm{hPa}$
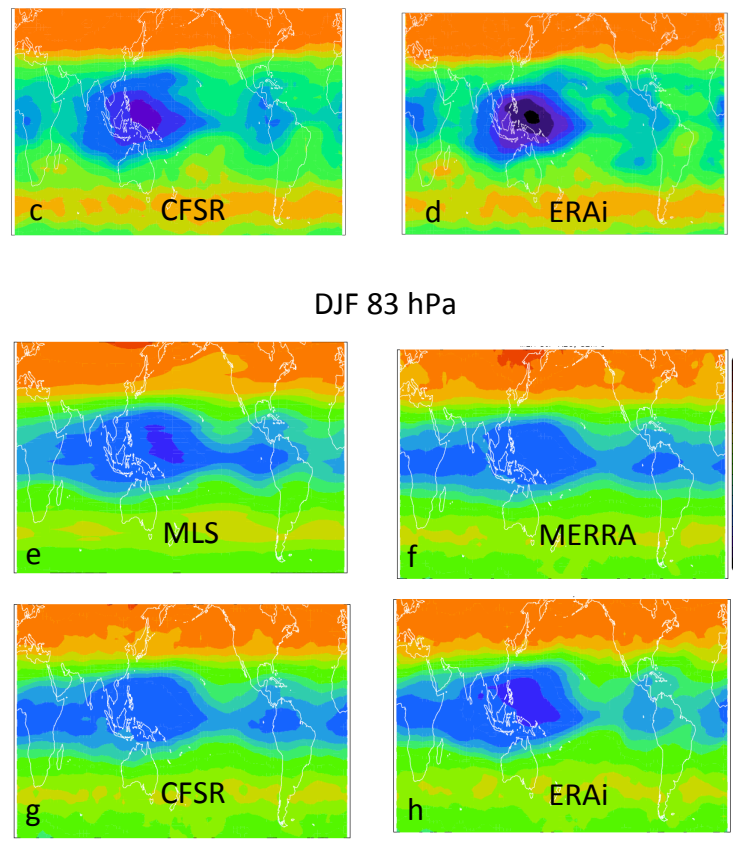
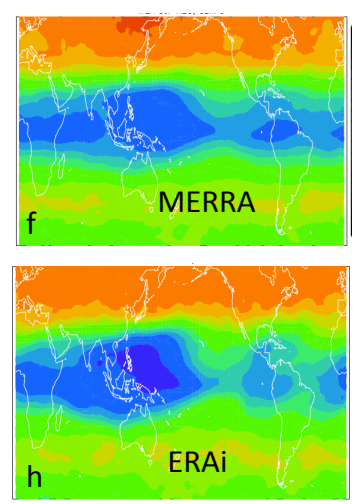
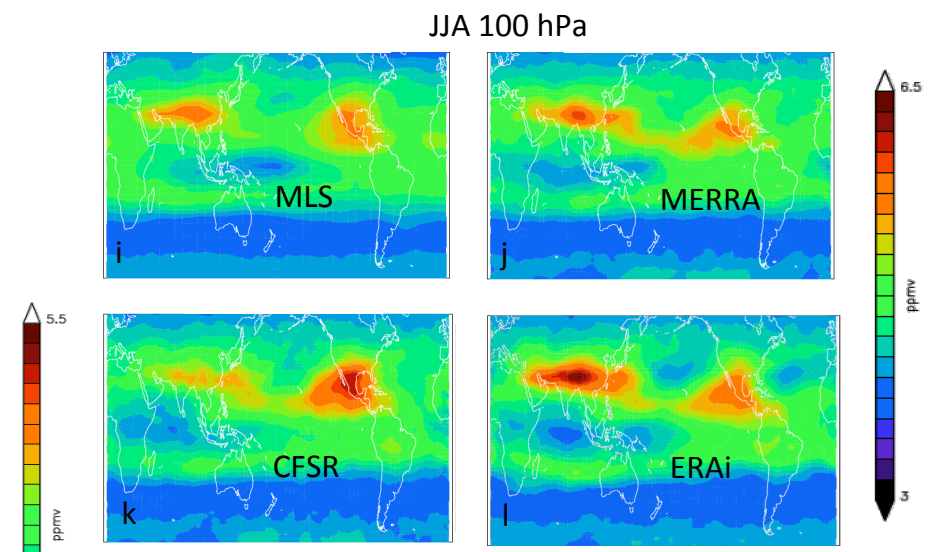

JJA $83 \mathrm{hPa}$
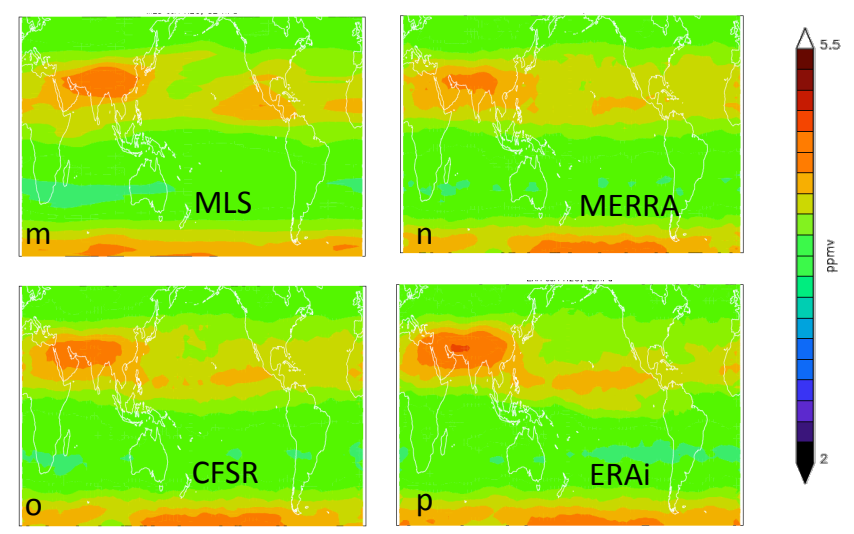

Fig. 2. Water vapor fields for winter at $100 \mathrm{hPa}(\mathbf{a}-\mathbf{d})$ and $83 \mathrm{hPa}(\mathbf{e}-\mathbf{h})$; and summer $100 \mathrm{hPa}(\mathbf{i}-\mathbf{l})$ and $83 \mathrm{hPa}(\mathbf{m}-\mathbf{p})$. The plots show $2005-$ 2010 five year averages of MLS and the models using the reanalyses indicated in each of the panels. The zonal mean water vapor fields are normalized to the zonal mean MLS field shown in the upper left of each quad-plot by multiplying by the zonal mean water vapor ratios at each latitude.

the water vapor feature over the Asian monsoon has enlarged while the Central/ South American feature is weaker. The Indian Ocean tropical dry feature has vanished. The Asian monsoon wet anomaly extends into the near east, and follows the heating zone shown in Fig. $1 \mathrm{~b}$.

The relatively good agreement between the MLS water vapor features and the model give us confidence that the model can be used to further understand water vapor anomalies in the upper troposphere. Dessler and Sherwood (2004) argued that the monsoonal high water vapor features are related to convection. Our model, however, does not include convective moistening, so this indicates that a model including only slow radiative ascent can also accurately simulate these features. Although convective moistening is required to explain the observed concentration of HDO in the stratosphere (Dessler et al., 2007), with the MERRA analysis the warmer tropopause in the monsoon leads to higher water vapor concentration so convective moistening is not required.

\subsection{Parcel displacement in the TTL}

Holton and Gettelman (2001) noted that parcels moving upward from the lower TTL into the stratosphere might travel long horizontal distances within the TTL. Trajectory calculations by Fueglistaler et al. (2004) (hereafter F2004) showed that the distances traveled could be tens of thousand of kilometers between $350 \mathrm{~K}$ and the dehydration point.

Following the approach of F2004 we can compute the distance between the parcel initiation and the point at which a parcel crosses the $370 \mathrm{~K}$ and $380 \mathrm{~K}$ surfaces - we refer to this distance as the displacement. The $370 \mathrm{~K}$ and $380 \mathrm{~K}$ surfaces bracket the coldest regions of the TTL and thus contain most of the final dehydration points. The $380 \mathrm{~K}$ surface is approximately the base of the stratosphere in the tropics. In Fig. 3 we show the gridded average displacement initialized parcels move before they cross the $370 \mathrm{~K}$ and $380 \mathrm{~K}$ surfaces for winter and summer seasons.

For winter the period, Fig. $3 \mathrm{a}$ and $\mathrm{b}$ show that there is very little displacement of parcels from 360 to $370 \mathrm{~K}$ over a region stretching from the Africa to the TWP, and South America. 


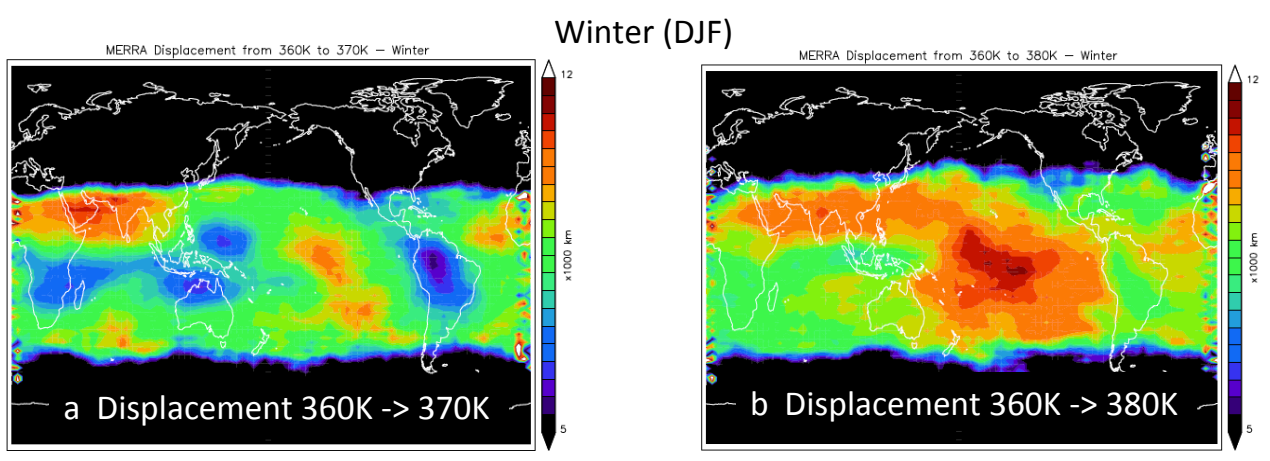

Summer (JJA)
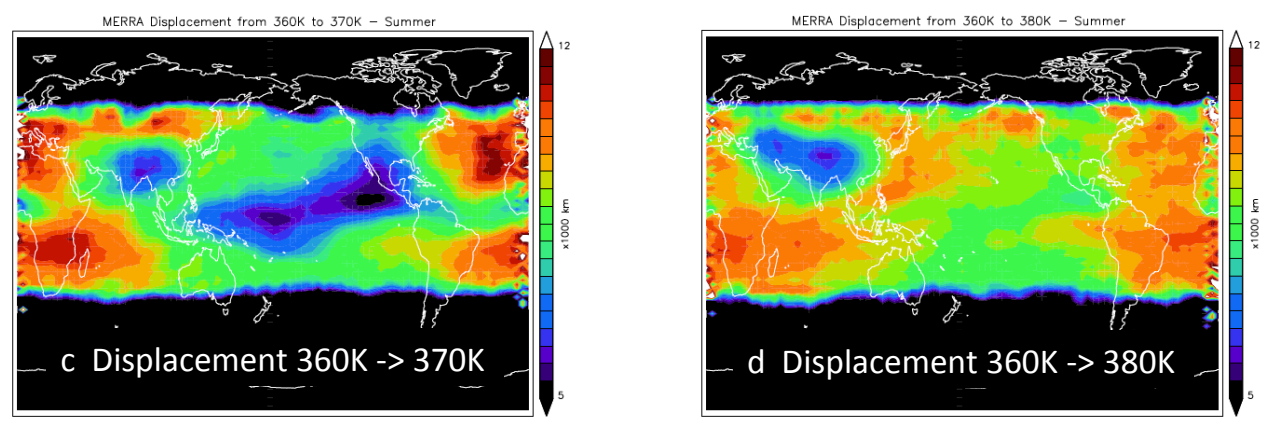

Fig. 3. The average displacement for parcels originating at $\sim 360 \mathrm{~K}$ reaching the $370 \mathrm{~K}$ and $380 \mathrm{~K}$ levels. (a), DJF for 360 to $370 \mathrm{~K}$; part (b) DJF for 360 to $380 \mathrm{~K}$; part (c) JJA for 360 to $370 \mathrm{~K}$, and (d) JJA for 360 to $380 \mathrm{~K}$. Displacement distances range from 5 to 12 thousand km.

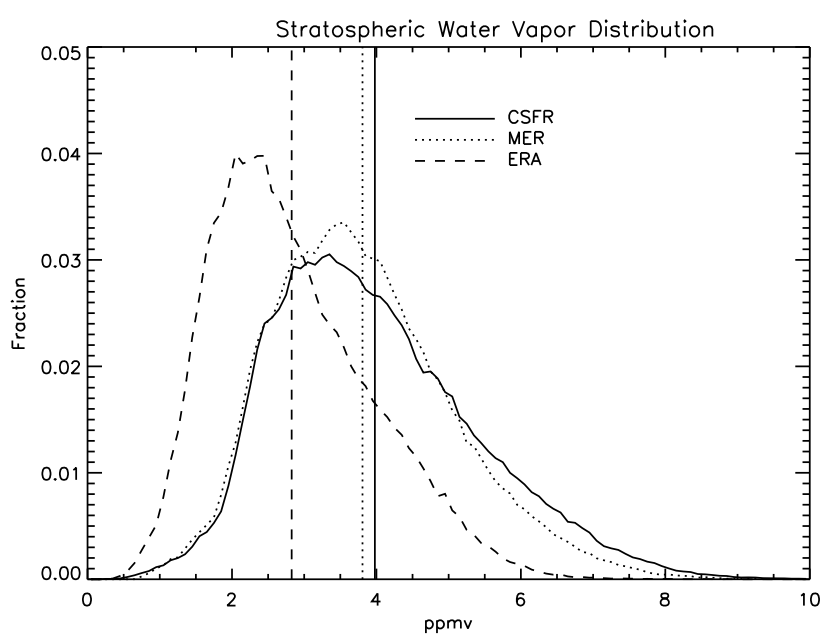

Fig. 4. PDF of water vapor concentration for parcels in the stratosphere. The PDF distribution is normalized by the total number of stratospheric parcels, bin size is 0.1 ppmv. The vertical lines indicate the mean value. ERAi is systematically drier and noted in S2012. Solid lines, CFSR; dotted lines, MERRA, and the dashed line ERAi (labeled ERA in figure).

Above $370 \mathrm{~K}$, the displacement is larger especially over the Eastern Pacific. The TWP upper troposphere consists of a cold pool dominated by a high pressure system (required by hydrostatic balance) in which air circulates around produc- ing little displacement. The strong diabatic heating in the TWP moves the air parcels rapidly up through this region. North of the TWP, the westerly subtropical jet moves parcels rapidly, thereby producing a large displacement. East of the TWP, a similar high-pressure system also develops over the South American cold pool. The polar jet dips equatorward between the TWP and South American system, creating a high-displacement zone in the East Pacific. The lowest displacement features - centered on the cold pools - correspond to the lowest winter water vapor anomalies shown in Fig. 2.

During summer, the tropical Pacific winds are weaker and air ascends to $370 \mathrm{~K}$ and $380 \mathrm{~K}$ without much displacement. In contrast to winter, the lowest displacement features correspond to high water vapor features seen in Fig. 2. The summer high-pressure system over the Asian monsoon region shows low displacement, and this low displacement feature extends up through $370 \mathrm{~K}$ to $380 \mathrm{~K}$. Bergman et al. (2013) has noted the almost complete isolation of the air within the Asian monsoon high-pressure system; back trajectories initiated within the upper troposphere anticyclone ascend almost directly from surface. The high water vapor anomalies over Central/South America also corresponds to a low displacement region but this displacement feature is not as dramatic at $380 \mathrm{~K}$.

The colocation of low displacement features and water vapor anomalies makes sense in that low displacement regions 

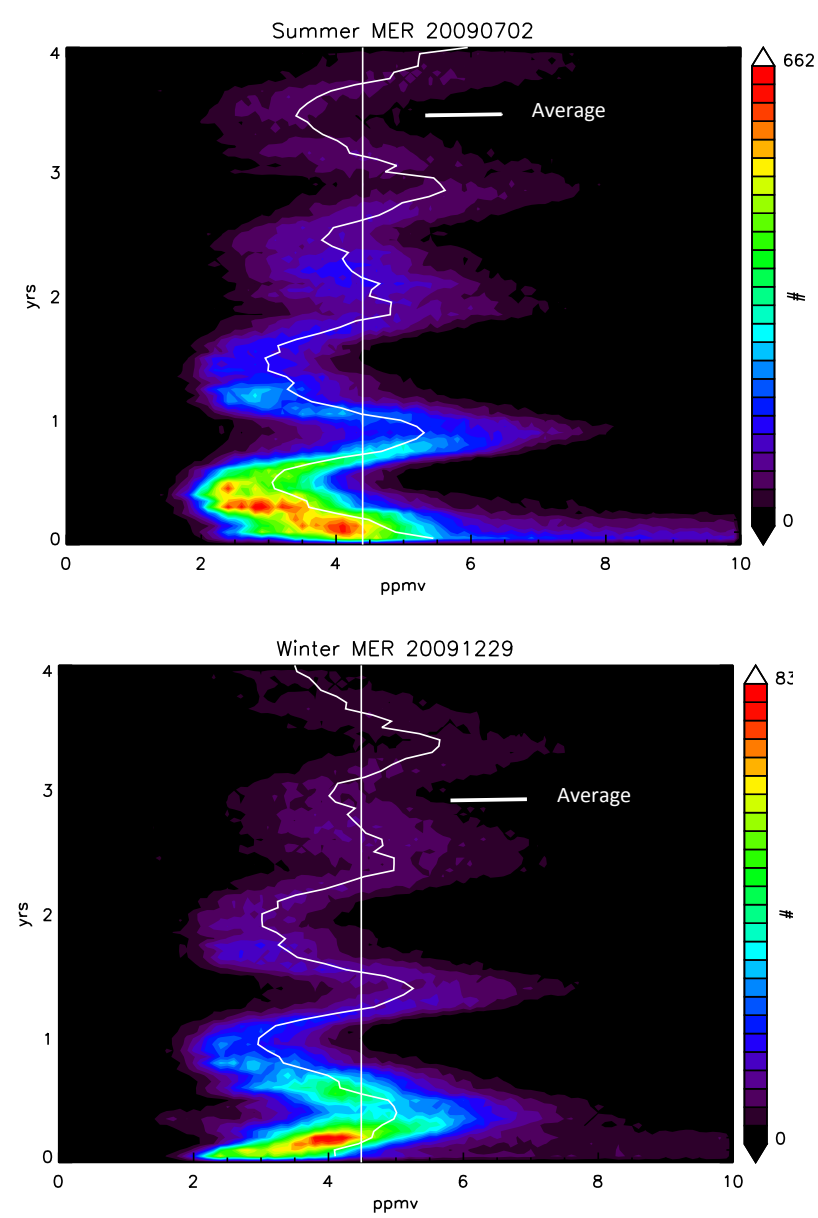

Fig. 5. Water vapor histogram using parcel age vs. water amount for the entire model domain above $18 \mathrm{~km}$. The seasonal oscillation in water vapor distribution is evident. As parcels age they may exit the stratosphere leading fewer parcels in the upper part of the plot. Units number of parcels per bin, 0.1 ppmv bin size for water; 0.05 year bin size for age.

are isolated so that their water vapor signatures are not diluted by mixing with surrounding air.

\subsection{Water vapor spectrum}

In order to further understand how water vapor is controlled within the stratosphere, we introduce the water vapor spectrum. The water vapor spectrum is analogous to the agespectrum (Waugh and Hall, 2002) - it is the probability distribution function (PDF) of water vapor concentration of stratospheric parcels and it follows from the ideas introduced by age-of-air studies (Schoeberl et al., 2000; Waugh and Hall, 2002). We define an "air sample" as a spatial region containing a number of parcels with different ages and water vapor concentrations. The sample age and water vapor amount are the ensemble average of parcel age and water vapor, respectively. The temperature along the parcel path into the
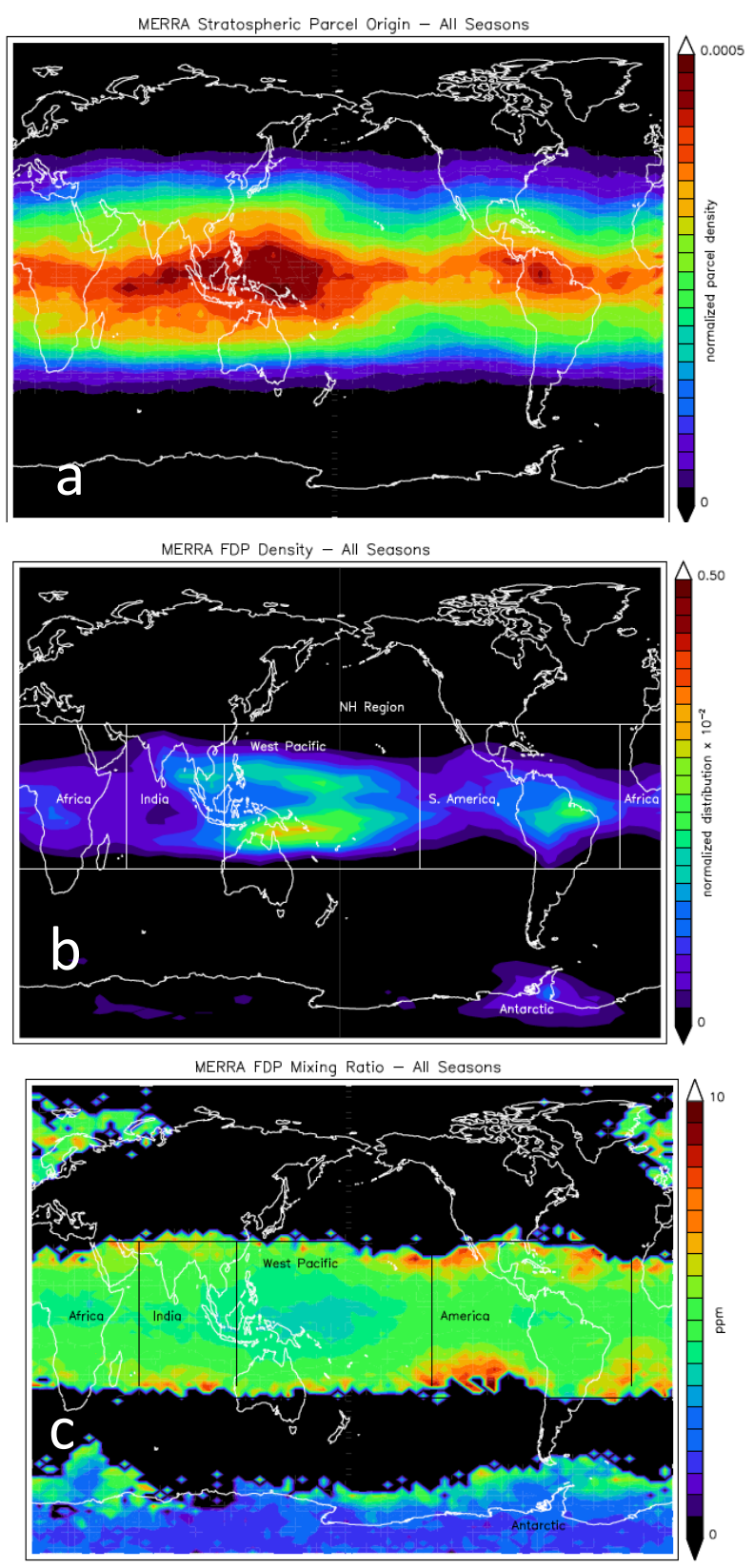

Fig. 6. Joint PDF of MERRA starting locations of parcels that ascended into the stratosphere vs. final water vapor values. Top, latitude vs. water vapor; bottom, longitude vs. water vapor. The color scheme and color bars referenced as in Fig. 1. The color indicates the number of parcels in a bin showing where the concentration of parcels is highest.

stratosphere determines the parcel's water vapor concentration, and the time it takes to travel the path determines the parcel age. This information is useful in understanding water vapor as well as understanding how short-lived ozone depleting substances might gain entry into the stratosphere (Salawitch et al., 2005; Levine et al., 2007). 

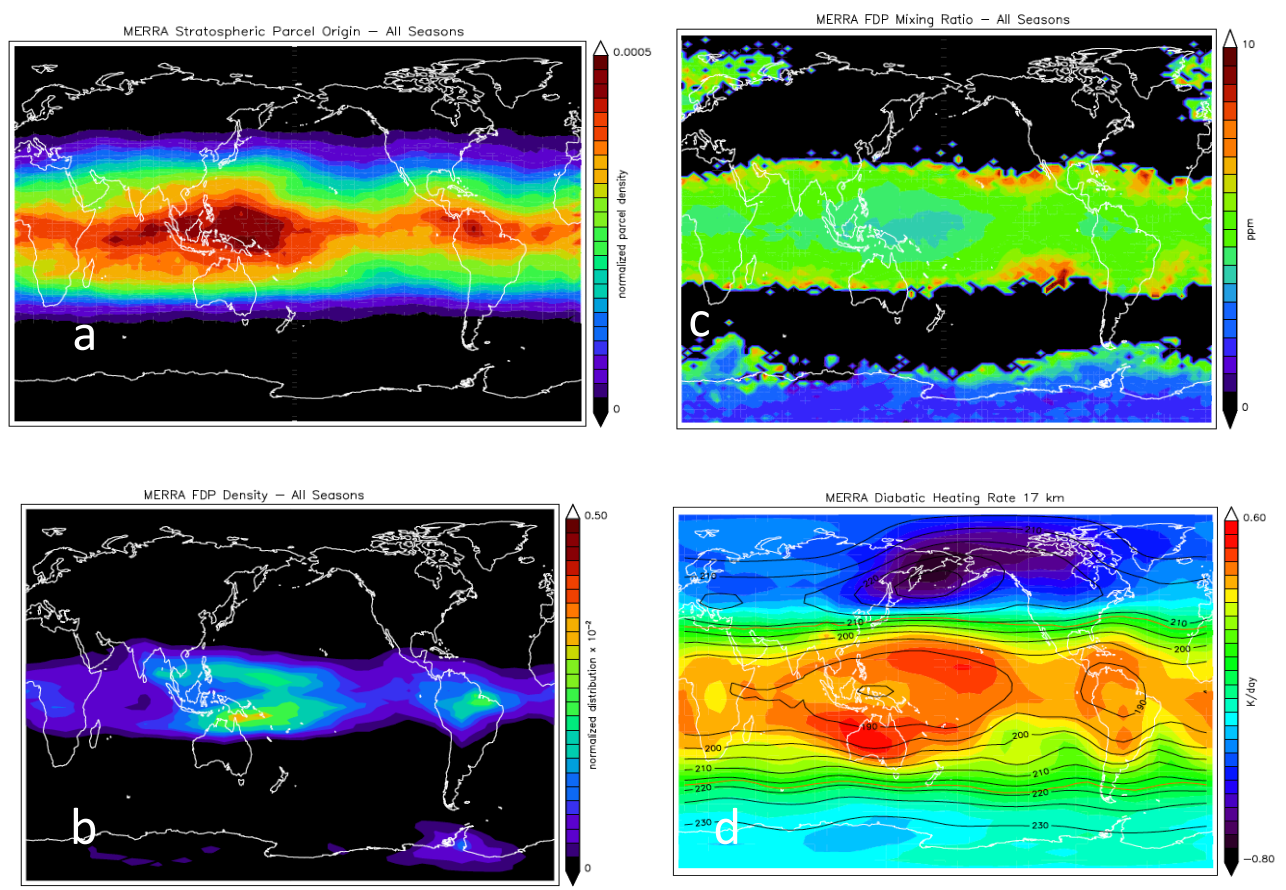

Fig. 7. Statistical results for parcels that end up in the stratosphere. (a), Density of origin points at the $360 \mathrm{~K}$ level. (b), density of final dehydration locations. (c), the average mixing ratio at the final dehydration point in $\mathrm{ppm}$. (d), annual average heating rate at $17 \mathrm{~km}$ in $\mathrm{Kday}^{-1}$ (as in Fig. 1).

Figure 4 shows the stratospheric water vapor spectrum for the three reanalyses. All parcels above $380 \mathrm{~K}$ are considered, and water from methane oxidation is not included since we are focusing on the tropopause dehydration process and the addition of water from oxidized methane would distort the distribution providing enhancing parcels that have reached higher altitudes. The distribution shown in Fig. 4 is fairly broad with values ranging from 0.5 to 9 ppmv and skewed toward higher values in all three cases. The skewed distribution weights the mean toward a higher concentration than the mode (distribution peak). This means that the wetter air parcels are driving stratospheric water vapor distribution away from the most frequently observed parcels - which, as noted below, come through the TWP region.

The overall ERAi dry bias (due to a colder upper troposphere, S2012) is evident in Fig. 4, even though the shape of the distribution is basically the same as the other analyses. Given the similarity in the distributions and water vapor anomaly fields, we will focus on MERRA for the rest of the paper. Figure 5 shows a two-dimensional histogram of the MERRA water-vapor spectrum vs. age (the time since the parcel was initialized). The oscillation of the water vapor field as a function of season is evident and consistent with warmer tropopause temperatures in summer vs. winter. This figure is basically the water vapor tape recorder without mixing (Mote et al., 1996).
Figure 6 shows the distribution of parcel initialization locations vs. water vapor amount in the stratosphere (parcels at altitudes greater than $380 \mathrm{~K}$ ) for all seasons. Figure 6a shows that the wettest parcels originate at relatively higher latitudes with the mean concentration nearly symmetric around a point just north of the equator. This is consistent with the temperature distributions in Fig. 1, namely that the region with highest temperature and net positive heating are at the edge of the tropics.

Figure $6 \mathrm{~b}$ shows the longitude distribution and it reveals two major source regions - the TWP and the Americas. These source regions are generally of higher heating rates in the TTL (Fig. 1). There is also the faint signature of Africa as a minor source region.

\subsection{Transport patterns}

Fueglistaler et al. (2004) showed that transport through the tropical west Pacific dominated transport from the troposphere to the stratosphere. Our calculations show similar results. Figure 7a shows the spatial density distribution of parcels originating at $\sim 360 \mathrm{~K}$ that end up in the stratosphere. This map can be visually compared to the final dehydration map (Fig. 7b). Overall the two maps are similar; the spatial correlation is $\sim 0.7$. Although we agree with F2004 that most of the air moving into the stratosphere is from the TWP, we also find that South America and Africa are significant source regions. This correlation between Fig. $7 \mathrm{a}$ and $\mathrm{b}$ is 

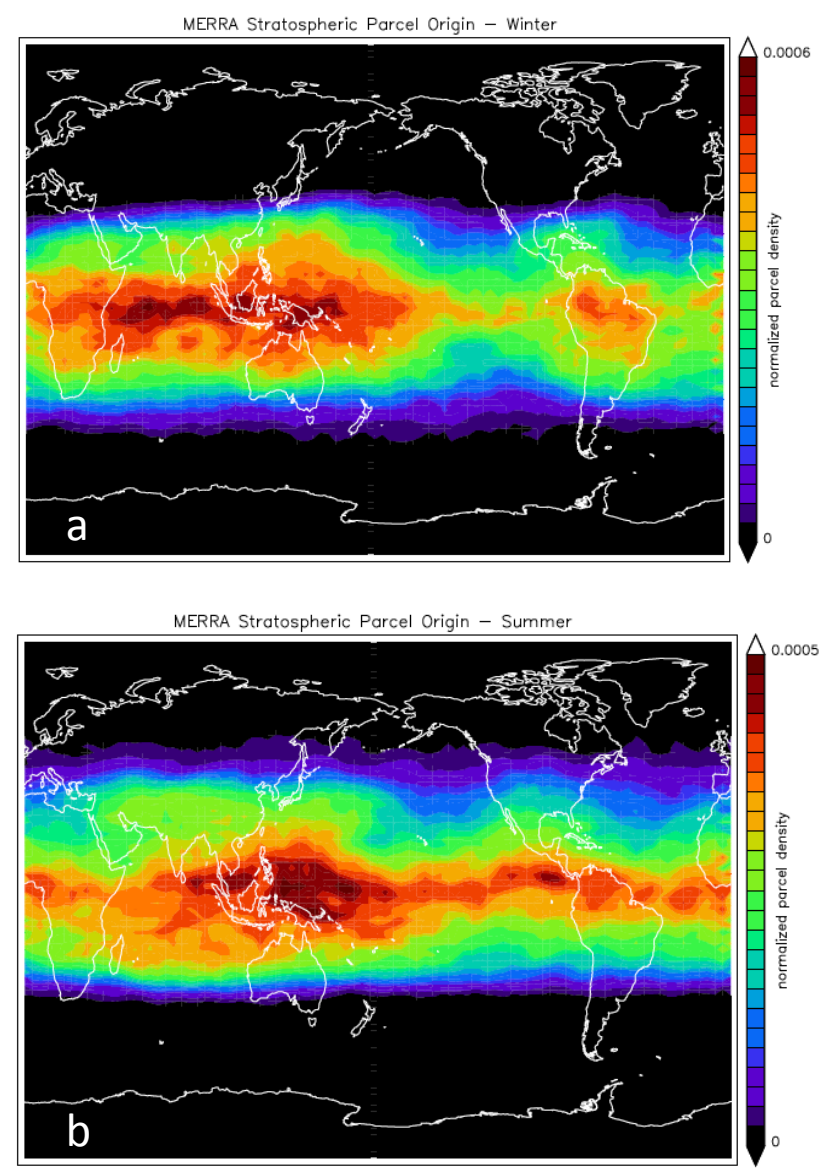

Fig. 8. Seasonal maps for TTL parcels that end up in the stratosphere (parcel origin). (a), Density map for $360 \mathrm{~K}$ parcels initiated during winter (DJF); (b), summer (JJA).

not surprising since the coldest regions of the TTL will also be the zones with strongest diabatic heating and provide the greatest opportunity for air parcels to enter the stratosphere. The major difference between the FDP and origin maps is that more parcels are originating on the edge of the tropics than one would assume simply by looking at the FDP plot. This means that there is a wider zone for pollutants to enter the stratosphere than might be assumed from the FDP pattern alone.

Figure $7 \mathrm{c}$ shows the mixing ratio of water vapor at the final dehydration points, which can be compared to Fig. 4 of F2004. Figure 7c shows that the wettest parcels are arriving from the edges of the tropics and the longitudes outside of the TWP, which F2004 noted as well. This also is seen in Fig. 6a. As an aside, Fig. 7c shows the effect of polar stratospheric dehydration of parcels (SD2011). Antarctic dehydration contributes to the systematically lower southern hemisphere water vapor concentration as observed by the MLS (SD2011) and HALOE (Rosenlof et al., 1997). As a reference, we show in Fig. $7 \mathrm{~d}$ the $17 \mathrm{~km}$ annual average heating rate and temperatures (similar to Fig. 1 but annual average). The strongest heating is in the TWP in zones north and south of the equator. The location of these ascent regions convolved with the temperature field gives rise to the FDP picture in Fig. 7b.

Figure 8 shows the seasonal dependency of the origin of parcels that reach the stratosphere. During winter (DJF) the dominant region is the equatorial west Pacific and Indian Ocean region. During the summer period, the parcel sources are predominately over the West Pacific and the ITCZ belt across the Pacific and Atlantic. Somewhat surprisingly, the Indian and North American monsoons do not appear as dominant features - even with strong heating in the monsoon regions (Fig. 1), the monsoons do not appear to be major pathways into the stratosphere despite their distinct appearance in $100 \mathrm{hPa}$ water vapor maps (Fig. 2) and in the displacement map (Fig. 3). The large positive heating rates over monsoon region drives parcels strongly upward, but because of the smaller area of this region, the monsoons are not as important an origin regions compared to the deeper tropics. ERAi and CFSR show similar results compared to MERRA. However, because of the higher water vapor due to the monsoons, those regions contribute disproportionately to the stratospheric water vapor.

The reason that the tropical belt of parcel sources is so broad compared to the density of FDP points is that the strong heating at the tropopause accelerates the air upward and forces convergence below and divergence above the tropopause. Thus, parcels well outside the location of the tropopause cold pools can be drawn into their stronger heating region near the equator - over the TWP or Central America or the Asian summer monsoon. This means it is possible that pollution detrained by convection or rising into the lower half of the TTL, but outside the TWP or other entry zones, can move into the stratosphere, as noted by Hosking et al. (2012).

\subsection{Sources of wet and dry parcels}

It is evident from the water vapor distributions (Fig. 2) that the wettest and driest parcels are experiencing different temperature histories as well. From Figs. 6a and 7c, and as noted above, the wettest parcels appear to originate at the edge of the tropics and in the low displacement zones associated with the monsoon (Fig. 3) while the driest parcels arise near winter TWP. Maps of where the wettest and driest parcels originate at $360 \mathrm{~K}$ (Fig. 9) bear this supposition out. The driest parcels originate deep within the tropics whereas the wettest parcels are more dispersed. Evidence of the monsoon influence appears in Fig. 9b with enhancements over India and Central America. Over India, the monsoon anticyclone in the upper troposphere pulls parcels from southern India around the anticyclone into the cold pool (Fig. 1b) where final dehydration occurs (Fig. 9d). In this region and over Central America, the tropopause is warmer than the TWP by $\sim 5 \mathrm{~K}$, so parcels following this path will experience less dehydration and produce higher water vapor anomalies. 

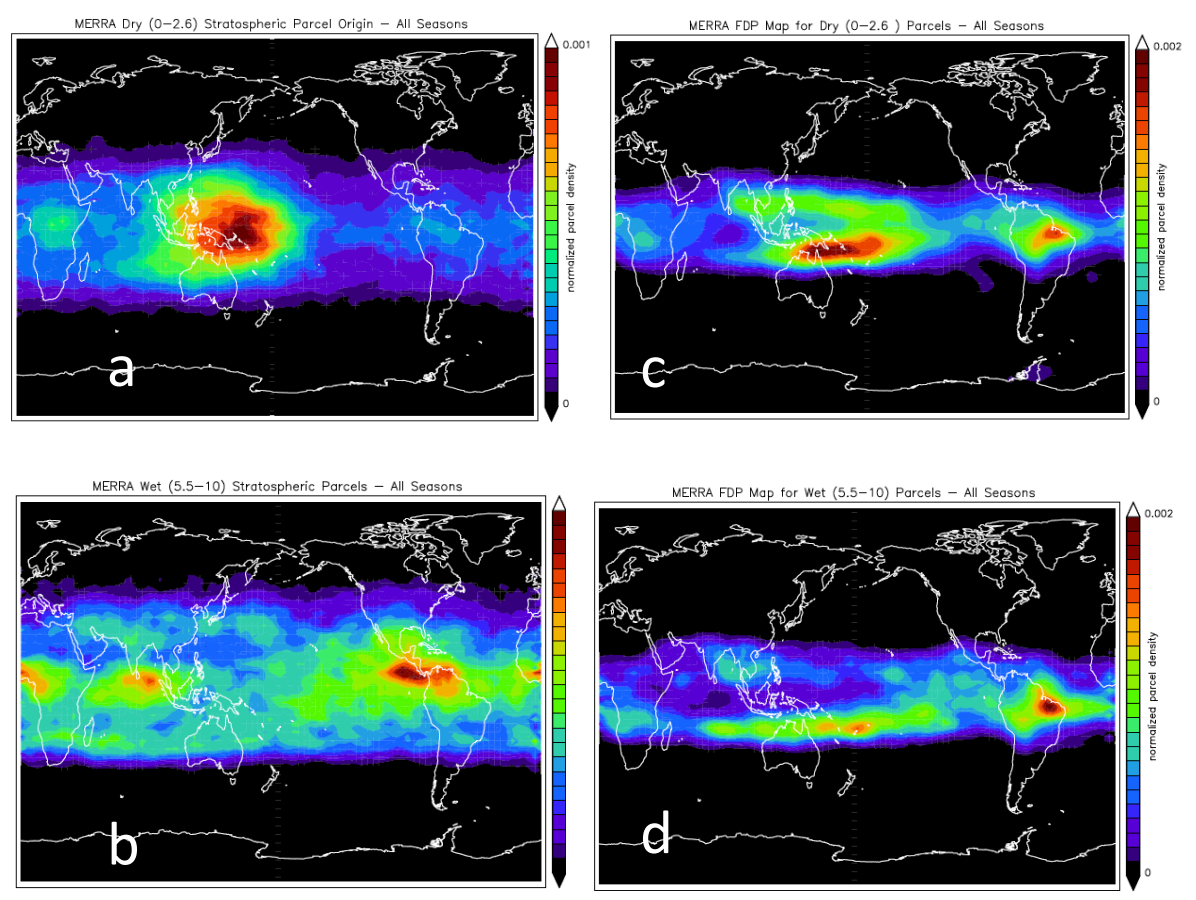

Fig. 9. $360 \mathrm{~K}$ parcel density maps of dry (a) and wet (b) parcels in the stratosphere and FDP density maps of the driest (c) and wettest (d) air. Wettest parcels (5.5-10 ppmv) are about $10 \%$ of the total number of parcels; driest (0-2.6 ppmv) are about $14 \%$.

\section{Summary and conclusions}

Using the forward domain filling trajectory model (SD2011 and S2012), we have investigated the processes that produce anomalies in the water vapor field. Our trajectory parcel statistics allow us to calculate the water vapor spectrum (analogous to the age-spectrum - a PDF of water vapor concentration, Fig. 4), which shows strong seasonal variations (Fig. 5) due to the variations in tropopause temperature which is the process that produces the water vapor tape recorder. The spectrum can be linked to pathways parcels take into the stratosphere. The final dehydration occurs mostly in a narrow region across the West Pacific, however the air parcels that end up in the stratosphere originate over a much wider area inside the TTL Driest air parcels originate in the core of the TWP whereas the wettest parcels originate at the edges of the TWP and South America in winter as well as the monsoons in summer (also noted by F2004).

We call the distance that parcels move from their initialization point the displacement. Displacement from initialization to $370 \mathrm{~K}$ and $380 \mathrm{~K}$ shows regional preferences of parcels with little movements. These include the winter TWP and summer Asian and American monsoon. The lowdisplacement regions correspond to locations of high and low water vapor anomalies. The anomalies occur because air is isolated in the low-displacement zones.

Figure 10 summarizes the view of winter air parcel processing implied by our results. The strong heating near the tropopause causes air to converge into the cold TWP region with divergence in the stratosphere above. Compared with the parcels at the tropical cold core, parcels at the edge of the tropical core experience warmer temperatures and weaker heating rates. Fewer of these less dehydrated parcels enter the stratosphere, but they skew the water vapor spectrum toward higher mean values. Along the equator, the TWP local maximum in the heating rate causes more parcels to preferentially ascend in the TWP where temperatures are colder, thus the predominance of FDPs near the TWP cold core. However, since the heating rate is positive throughout the tropics, parcels can still ascend into the stratosphere outside the TWP region leading to the population of wetter parcels ascending over South America, for example.

Our results suggest that it is important to understand what controls both the wet and dry parcels. A decrease in TWP temperatures would shift the stratospheric water vapor concentration lower, while an increase in wet parcel concentration, parcels that enter the stratosphere outside of the TWP, would have the effect in increasing stratospheric water. Central and South America consistently appear as zones of entry for wetter air parcels.

The understanding that there are a variety of zones from which parcels move into the stratosphere even with mixing ratios well above the mean (see Fig. 3) suggests that there are more opportunities for polluted air to enter the stratosphere than just the TWP or the Asian monsoon region. 

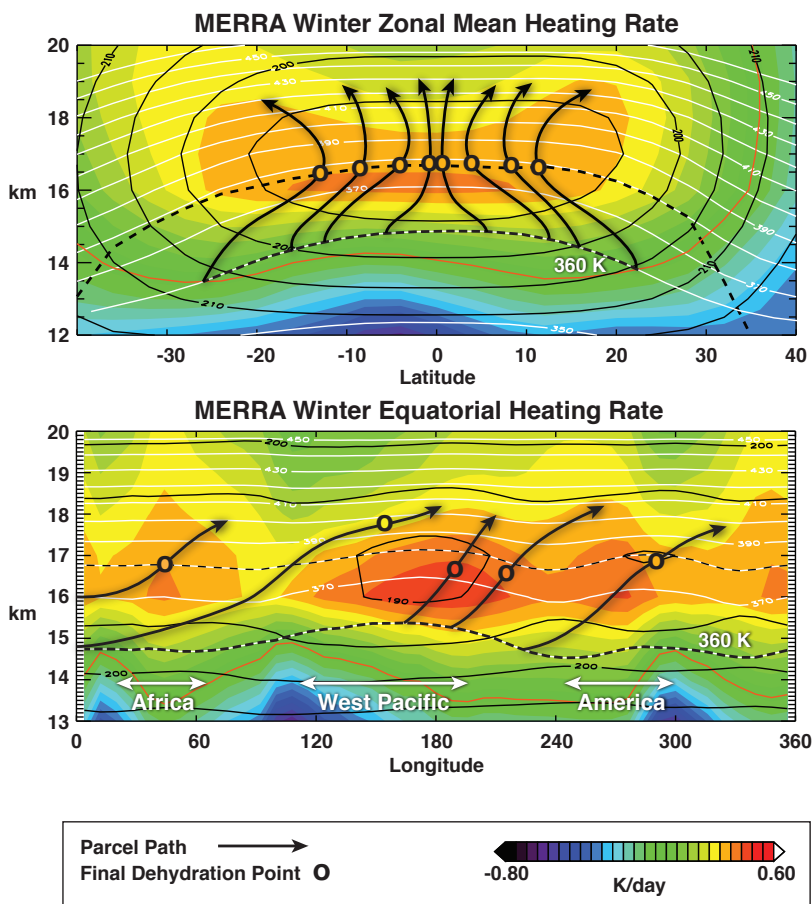

Fig. 10. Diagram of the dehydration process. Parcel paths for parcels entering the stratosphere are shown as black arrows. The color background shows the heating rate $\left(\mathrm{K} \mathrm{day}^{-1}\right)$ from MERRA; black contours are temperature $(\mathrm{K})$, and white contours are potential temperature $(\mathrm{K})$. Thin dashed black line is the tropopause, thick dashed black line is $360 \mathrm{~K}$ surface - roughly the level where parcels in our model are initialized. Top figure is zonal mean cross section where the air parcels moving upward concentrate latitudinally at the tropopause before rising into the stratosphere. Lower figure shows parcel paths vs. longitude along the equator. Small circles in both figures indicate the final dehydration points showing that the dehydration can take place at different altitudes. See text for details.

Acknowledgements. A. Dessler acknowledges NASA Aura grant NNX08AR27G to Texas A\&M University. We thank K. Bowman for help on the trajectory code. Figure 10 was produced by Barbara Schoeberl with our thanks.

Edited by: W. Lahoz

\section{References}

Bergman, J. W., Fierli, F., Jensen, E., Honomicht, S., and Pan, L.: Boundary layer sources for the Asian anticyclone: Regional contributions to a vertical conduit, J. Geophys. Res., 118, doi:10.1002/jgrd.50142, 2013.

Boville, B. W.: The Aleutian Stratospheric Anticyclone, J. Meteorol. 17, 329-336, 1960.

Brewer, A. W.: Evidence for a world circulation provided by the measurements of helium and water vapour distribution in the stratosphere, Q. J. Roy. Meteorol. Soc., 75, 351-363, 1949.
Corti, T., Luo, B. P., Fu, Q., Vömel, H., and Peter, T.: The impact of cirrus clouds on tropical troposphere-to-stratosphere transport, Atmos. Chem. Phys., 6, 2539-2547, doi:10.5194/acp-6-25392006, 2006.

Dee, D. P., Uppala, S. M., Simmons, A. J., Berrisford, P., Poli, P., Kobayashi, S., Andrae, U., Balmased, M. A., Balsamo, G., Bauer, P., Bechtold, P., Beljaars, A. C. M., van de Berg, L., Bidlot, J., Bormann, N., Delsol, C., Dragani, R., Fuentes, M., Geer, A. J., Haimberger, L., Healy, S. B., Hersbach, H., Hólm, E. V., Isaksen, L., Kållberg, P., Köler, M., Matricardi, M., McNally, A. P., Monge-Sanz, B. M., Morcrette, J.-J., Park, B.-K., Peubey, C., de Rosnay, P., Tavolato, C., Thépaut, J.-N., and Vitart, F.: The ERA-Interim reanalysis: configuration and performance of the data assimilation system, Q. J. Roy. Met. Soc., 137, 553-597, doi:10.1002/qj.838, 2011.

Dessler, A. E.: The effect of deep, tropical convection on the tropical tropopause layer, J. Geophys. Res., 107, 4033, doi:10.1029/2001JD000511, 2002.

Dessler, A. E. and Sherwood, S. C.: The effect of convection on the summertime extratropical lower stratosphere, J. Geophys. Res., 109, D23301, doi:10.1029/2004JD005209, 2004.

Dessler, A. E., Hanisco, T. F., and Fueglistaler, S.: Effects of convective ice lofting on $\mathrm{H}_{2} \mathrm{O}$ and $\mathrm{HDO}$ in the tropical tropopause layer, J. Geophys. Res., 112, D18309, doi:10.1029/2007JD008609, 2007.

Fleming, E. L., Jackman, C. H., Weisenstein, D. K., and Ko, M.: The impact of inter-annual variability on multi- decadal total ozone simulations, J. Geophys. Res., 112, D10310, doi:10.1029/2006JD007953, 2007.

Folkins, I. and Martin, R. V.: The vertical structure of tropical convection, and its impact on the budgets of water vapor and ozone, J. Atmos. Sci., 62, 1560-1573, 2005.

Fueglistaler, S., Wernli, H., and Peter, T.: Tropical troposphereto-stratosphere transport inferred from trajectory calculations, J. Geophys. Res., 109, D03108, doi:10.1029/2003JD004069, 2004.

Fueglistaler, S., Bonazzola, M., Haynes, P. H., and Peter, T.: Stratospheric water vapor predicted from the Lagrangian temperature history of air entering the stratosphere in the tropics, J. Geophys. Res., 110, D08107, doi:10.1029/2004JD005516, 2005.

Fueglistaler, S., Dessler, A. E., Dunkerton, T. J., Folkins, I., Fu, Q., and Mote, P. W.: The tropical tropopause layer, Rev. Geophys., 47, RG1004, doi:10.1029/2008RG000267, 2009.

Gettelman, A. and Forster, P. M. F.: A climatology of the tropical tropopause layer, J. Meteorol. Soc. Jpn., 80, 911-924, 2002.

Gettelman, A., Randel, W. J., Wu, F. and Massie, S. T.: Transport of water vapor in the tropical tropopause layer, Geophys. Res. Let., 29, 1009, doi:10.1029/2001GL013818, 2002.

Gettelman, A., Hegglin, M. I., Son, S. W., Kim, J., Fujiwara, M., Birner, T., Kremser, S., Rex, M., Añel, J. A., Akiyoshi, H., Austin, J., Bekki, S., Braesike, P., Brühl, C., Butchart, N., Chipperfield, M., Dameris, M., Dhomse, S., Garny, H., Hardiman, S. C., Jöckel, P., Kinnison, D. E., Lamarque, J. F., Mancini, E., Marchand, M., Michou, M., Morgenstern, O., Pawson, S., Pitari, G., Plummer, D., Pyle, J. A., Rozanov, E., Scinocca, J., Shepherd, T. G., Shibata, K., Smale, D., Teyssédre, H., and Tian, W.: Multimodel assessment of the upper troposphere and lower stratosphere: Tropics and global trends, J. Geophys. Res., 115, D00M08, doi:10.1029/2009JD013638, 2010. 
Holton, J. R. and Gettelman, A.: Horizontal transport and dehydration in the stratosphere, Geophys. Res. Lett., 28, 2799-2802, 2001.

Holton, J. R., Haynes, P. H., McIntyre, M. E., Douglass, A. R., Rood, R. B., and Pfister, L.: Stratosphere-troposphere exchange, Rev. Geophys., 33, 403-439, 1995.

Hosking, J. S., Russo, M. R., Braesicke, P., and Pyle, J. A.: Tropical convective transport and the Walker circulation, Atmos. Chem. Phys., 12, 9791-9797, doi:10.5194/acp-12-9791-2012, 2012.

Hosking, J. S., Russo, M. R., Braesicke, P., and Pyle, J. A.: Tropical convective transport and the Walker circulation, Atmos. Chem. Phys., 12, 9791-9797, doi:10.5194/acp-12-9791-2012, 2012.

Jensen, E. J. and Pfister, L.: Transport and freeze-drying in the tropical tropopause layer, J. Geophys. Res., 109, D02207, doi:10.1029/2003JD004022, 2004.

Jensen E. J., Toon O. B., Pfister L., and Selkirk, H. B.: Dehydration of the upper troposphere and lower stratosphere by subvisible cirrus clouds near the tropical tropopause, Geophys. Res. Lett., 23, 835-838, 1996.

Levine, J. G., Braesicke, P., Harris, N., Savage, N., and Pyle, J. A.: Pathways and timescales for troposphere-to-stratosphere transport via the tropical tropopause layer and their relevance for very short lived substances, J. Geophys. Res., 112, 1-15, doi:10.1029/2005JD006940, 2007.

Liu, Y. S., Fueglistaler, S., and Haynes, P.: Advection-condensation paradigm for stratospheric water vapor, J. Geophys. Res., 115, D24307, doi:10.1029/2010JD014352, 2010.

Mote, P. W., Rosenlof, K. H., McIntyre, M. E., Carr, E. S., Gille, J. C., Holton, J. R., Kinnersley, J. S., Pumphrey, H. C., Russell III, J. M., and Waters, J. W.: An atmospheric tape recorder: The imprint of tropical tropopause temperatures on stratospheric water vapor, J. Geophys. Res., 101, 3989-4006, 1996.

Murphy, D. M. and Koop, T.: Review of the vapour pressures of ice and supercooled water for atmospheric applications, Q. J. Royal Met. Soc., 131, 1539-1565, 2005.

Newell, R. E. and Gould-Stewart, S.: A Stratospheric Fountain?, J. Atmos. Sci., 38, 2789-2796, 1981.

Read, W. G., Lambert, A., Bacmeister, J., Cofield, R. E., Christensen, L. E., Cuddy, D. T., Daffer, W. H., Drouin, B. J., Fetzer, E., Froidevaux, L., Fuller, R., Herman, R., Jarnot, R. F., Jiang, J. H., Jiang, Y. B., Kelly, K., Knosp, B. W., Kovalenko, L. J., Livesey, N. J., Liu, H.-C., Manney, G. L., Pickett, H. M., Pumphrey, H. C., Rosenlof, K. H., Sabounchi, X., Santee, M. L., Schwartz, M. J., Snyder, W. V., Stek, P. C., Su, H., Takacs, L. L., Thurstans, R. P., Vömel, H., Wagner, P. A., Waters, J. W., Webster, C. R., Weinstock, E. M., and Wu, D. L.: Aura Microwave Limb Sounder upper tropospheric and lower stratospheric $\mathrm{H}_{2} \mathrm{O}$ and relative humidity with respect to ice validation, J. Geophys. Res., 112, D24S35, doi:10.1029/2007JD008752, 2007.

Quack, B. and Wallace, D. W. R.: Air-sea flux of bromoform: Controls, rates, and implications, Global Biogeochem. Cy., 17, 1023, doi:10.1029/2002GB001890, 2003.

Randel, W. J., Wu, F., Oltmans, S. J., Rosenlof, K., and Nedoluha, G.: Interannual Changes of Stratospheric Water Vapor and Correlations with Tropical Tropopause Temperatures, J. Atmos. Sci., 61, 2133-2148, 2004.
Randel, W. J., Park, M., Emmons, L., Kinnison, D., Bernath, P., Walker, K. A., Boone, C., and Pumphrey, H.: Asian Monsoon Transport of Pollution to the Stratosphere, Science 328, 611, doi:10.1126/science, 2010.

Rienecker, M., Suarez, M. J., Gelaro, R., Todling, R., Bacmeister, J., Liu, E., Bosilovich, M. G., Schubert, S. D., Takacs, L., Kim, G.-K., Bloom, S., Chen, J., Collins, D., Conaty, A., da Silva, A., Gu, W., Joiner, J., Koster, R. D., Lucchesi, R., Molod, A., Owens, T., Pawson, S., Pegion, P., Redder, C. R., Reichle, R., Robertson, J., F. R., Ruddick, A. G., Sienkiewicz, M., Woollen: MERRA: NASA's Modern-Era Retrospective Analysis for Research and Applications, J. Climate, 24, doi:10.1175/JCLI-D-1100015.1, 3624-3648, 2011.

Rosenlof, K. H., Tuck, A. F., Kelly, K. K., Russell, J. M., and McCormick, M. P.: Hemispheric asymmetries in water vapor and inferences about transport in the lower stratosphere. J. Geophys. Res., 102, 13213-13234, 1997.

Saha, S., Moorthi, S., Pan, H.-L., Wu, X., J. Wang, S. Nadiga, P. Tripp, R. Kistler, J. Woolen, D. Behringer, H. Liu, D. Stokes, R. Grumbine, G. Gayno, J. Wang, Y.-T. Hou, H. Chuang, HannMing H. Juang, J. Sela, M. Iredell , R. T., D. Kleist, P. Van Delst, D. Keyser, J. Derber, M. Ek, J. Meng, H. Wei, R. an Yang, S. Lord, H. van den Dool, A. Kumar, W. Wang, C. Long, M. Chelliah, Y. Xue, Bo. Huang, J.-K. Schemm, W. Ebisuzaki, R. Lin, P. Xie, M. Chen, S. Zhou, W. Higgins, C.-Z. Zou, Q. Liu, Y. Chen, Y. Han, L. Cucurull, R. W. Reynolds, G. Rutledge, and M. Goldberg: The NCEP Climate Forecast System Reanalysis. Bull. Amer. Meteor. Soc., 91, 1015-1057, 2010.

Salawitch, R. J., Weisenstein, D. K., Kovalenko, L. J., Sioris, C. E., Wennberg, P. O., Chance, K., Ko, M. K. W., and Mclinden, C. A.: Sensitivity of ozone to bromine in the lower stratosphere, Geophys, Res. Lett., 32, L05811, doi:10.1029/2004GL021504, 2005

Schiller, C., Grooß, J.-U., Konopka, P., Plöger, F., Silva dos Santos, F. H., and Spelten, N.: Hydration and dehydration at the tropical tropopause, Atmos. Chem. Phys., 9, 9647-9660, doi:10.5194/acp-9-9647-2009, 2009.

Schoeberl, M. R. and Dessler, A. E.: Dehydration of the stratosphere: Atmos. Chem. Phys., 11, 8433-8446, 2011, http://www.atmos-chem-phys.net/11/8433/2011/.

Schoeberl, M. R., Sparling, L., Jackman, C., and Fleming, E.: A Lagrangian view of stratospheric trace gas distributions, J. Geophys. Res., 105, 1537-1552, 2000.

Schoeberl, M. R., Dessler, A. E., and Wang, T.: Simulation of stratospheric water vapor and trends using three reanalyses, Atmos. Chem. Phys., 12, 6475-6487, doi:10.5194/acp-12-6475-2012, 2012.

Sherwood, S. C. and Dessler, A. E.: On the control of stratospheric humidity, Geophys. Res. Lett., 27, 2513-2516, 2000.

Waugh, D. W. and Hall, T. M.: Age of stratospheric air: Theory, observations, and models, Rev. Geophys., 40, 1010, doi:10.1029/2000RG000101, 2002.

Zipser, E. J., Cecil, D. J., Liu, C., Nesbitt, S. W., and Yorty, D. P.: Where are the most intense thunderstorms on Earth?, Bull. Am. Met. Soc., 87, 1057-1071, 2006. 